Zeszyty Naukowe Szkoły Głównej Gospodarstwa Wiejskiego

Ekonomika i Organizacja Gospodarki Żywnościowej nr 115, 2016: 23-35

Dorota Starzyńska, Marta Baraniak

Wydział Zarządzania

Uniwersytet Łódzki

\title{
Profil działalności indywidualnych gospodarstw rolnych a korzyści z VAT
}

\section{Wstęp}

Podatek VAT w polskim rolnictwie funkcjonuje od 2000 roku. Jednak świadomość rolników w tej dziedzinie jest nadal niezadowalająca. Podczas wyboru formy opodatkowania nie dostrzegają oni barier o formalnym i organizacyjnym podłożu. A tymczasem błędny wybór sposobu rozliczania podatku VAT skutkuje znikomymi korzyściami finansowymi, a nawet możliwym wystąpieniem dużych nadwyżek podatku należnego nad naliczonym.

Działalność rolnicza jest specyficzną formą działalności nieobjętą ustawą o podatku dochodowym od osób fizycznych czy też prawnych. Jedynym obowiazkiem podatkowym rolnika jest podatek rolny. Posiada on jednak prawo wyboru formy rozliczania się z podatku VAT. Przy dokonywaniu tego wyboru należy wziąc pod uwagę obecnie obowiązujące przepisy podatku od towarów i usług, w tym szczególnie stawki podatkowe na towary wytwarzane i zakupywane przez gospodarstwo. Istotne są również aspekty ekonomiczne, takie jak skala i profil prowadzonej działalności oraz struktura wpływów i wydatków w gospodarstwie. Podatek VAT stanowi element zarządzania gospodarstwem rolnym, dlatego podczas ostatecznego wyboru należy uwzględnić jego wpływ na stan finansów gospodarstwa.

\section{System podatku VAT w działalności indywidualnych gospodarstw rolnych}

Rolnik ma prawo rozliczać się z podatku VAT według dowolnie wybranej przez siebie formy. Ustawa o podatku od towarów i usług z dnia 11 marca 2004 
roku zawiera obszerną definicję działalności rolniczej ${ }^{1}$. W myśl przepisów ustawy wyróżnić można dwie kategorie rolników:

- rolnik ryczałtowy, który korzysta ze zwolnienia od podatku VAT (z wykluczeniem rolników, którzy są zobligowani do prowadzenia ksiąg rachunkowych na podstawie art. 2 ustawy o rachunkowości),

- rolnik opodatkowany na zasadach ogólnych, który złożył zgłoszenie o zarejestrowanie jako podatnik VAT.

Rolnikiem ryczałtowym jest rolnik, który dokonuje dostaw produktów rolnych pochodzących z własnej działalności rolniczej bądź świadczy usługi rolnicze. W tym przypadku zasadniczy ciężar podatku VAT spada na podatników VAT, którzy dokonują zakupów od rolników ryczałtowych. Są oni ustawowo zobowiązani do wystawiania faktur dokumentujących zakup produktów rolnych od rolników ryczałtowych i wypłacania im rekompensat z tytułu płaconych przez tych rolników podatków w dokonywanych przez nich zakupach środków niezbędnych do prowadzenia działalności rolniczej. Rekompensata ta nazywana jest zryczałtowanym zwrotem podatku i aktualnie wynosi 6,5\% wartości nabytych produktów [Ustawa ... 2004, art. 115]. Szczególną procedurę umożliwiającą otrzymanie zryczałtowanego zwrotu podatku przedstawia rysunek.

Specyfika działalności rolniczej wymaga specyficznych form rozliczania podatku od towarów i usług. Najważniejszą różnicą między gospodarstwem rolnym a inną formą działalności gospodarczej jest zryczałtowany zwrot podatku VAT. Stanowi on swoistą zachętę, aby zwiększać poziom produkcji [Arsenowic i in., 2012, s. 232]. Jest także maksymalnym ułatwieniem dla rolników w kwestii ewidencyjnej. Jednak wadą tego systemu jest brak możliwości odliczenia podatku zapłaconego przy zakupie środków niezbędnych do prowadzenia działalności rolniczej. Ta forma opodatkowania jest dobra dla małych gospodarstw, które nie planują realizacji inwestycji w postaci maszyn rolniczych bądź budynków gospodarczych [Zabielska 2011, s. 64].

\footnotetext{
${ }^{1}$ Ustawa określa działalność rolniczą jako „produkcję roślinną i zwierzęcą, w tym również produkcję materiału siewnego, szkółkarskiego, hodowlanego oraz reprodukcyjnego, produkcję warzywniczą, gruntową, szklarniową i pod folia, produkcję roślin ozdobnych, grzybów uprawnych i sadowniczą, chów, hodowlę i produkcję materiału zarodowego zwierząt, ptactwa i owadów użytkowych, produkcję zwierzęcą typu przemysłowego lub fermowego oraz hodowlę ryb i innych organizmów żyjących w wodzie, a także uprawy w szklarniach i ogrzewanych tunelach foliowych, uprawy grzybów i ich grzybni, uprawy roślin »in vitro«, fermową hodowlę i chów drobiu rzeźnego i nieśnego, wylęgarnie drobiu, hodowlę i chów zwierząt futerkowych i laboratoryjnych, chów i hodowlę dżdżownic, entomofagów i jedwabników, prowadzenie pasiek oraz chów i hodowlę innych zwierząt poza gospodarstwem rolnym oraz sprzedaż produktów gospodarki leśnej i łowieckiej, z wyjątkiem drewna okrąłłego z drzew tropikalnych (PKWiU 02.20.13.0) oraz bambusa (PKWiU ex 01.29.30.0), a także świadczenie usług rolniczych”.
} 


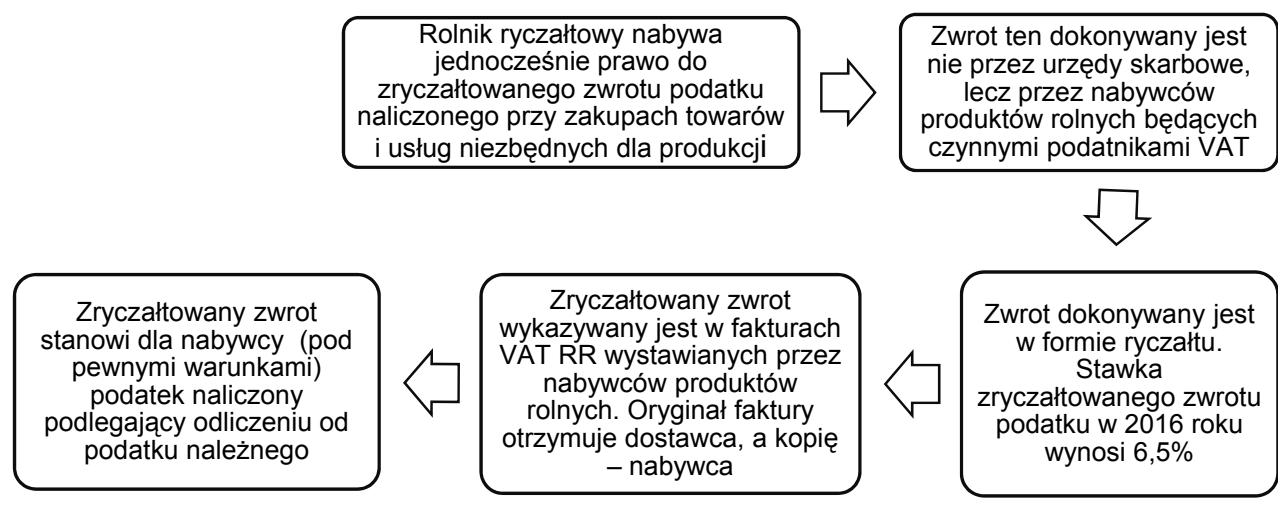

Rysunek

Procedura otrzymania zryczałtowanego zwrotu podatku

Źródło: Opracowanie własne na podstawie Bielęda i inni [2012, s. 379].

Obowiązek przejścia na zasady ogólne pojawia się w momencie, gdy przychody ze sprzedaży towarów lub usług przekroczyły w poprzednim roku obrotowym kwotę 150 tys. zł.

Jeżeli rolnik zrezygnuje ze zwolnienia z VAT-u, to dopiero po upływie trzech lat od daty rezygnacji oraz przejścia na zasady ogólne będzie mógł odzyskać status rolnika ryczałtowego [Ustawa... 2004, art. 43]. Będąc czynnym płatnikiem VAT, rolnik jest zobowiązany do każdorazowego wystawiania faktur sprzedaży VAT, jak również dokumentowania zużycia produktów rolnych dla potrzeb funkcjonowania gospodarstwa rolnego (faktura wewnętrzna), a także wszelkiego rodzaju darowizny.

Rolnik musi stosować odpowiednią stawkę podatku VAT, bez względu na sposób, w jaki będzie się rozliczał. Podstawowa wynosi $23 \%$, a większość produktów żywnościowych opodatkowana jest najniższą stawką, która wynosi 5\%. Niektóre towary i usługi ( $\mathrm{w}$ tym także związane z rolnictwem) opodatkowane są stawką obniżoną, która obecnie wynosi $8 \%$. Towary i usługi sprzedawane poza granicami kraju opodatkowane są stawką $0 \%$.

Reasumując, Polska wykazała znaczną dyscyplinę przy wprowadzaniu podatku VAT w rolnictwie po integracji z Unią Europejską. Obecnie rolnik sam wybiera metodę rozliczania z podatku VAT, która jest dla niego najbardziej odpowiednia, a przy tym opłacalna. Należy pamiętać, iż mechanizm rozliczeń podatku VAT powinien być wygodny zarówno dla gospodarstw domowych, jak i całego społeczeństwa [Frecauteanu i Chislaru 2013, s. 159]. Ewidencja podatkowa nie jest zatem skomplikowana, a jej ewentualne prowadzenie nie nastręcza kłopotów rolnikowi, ponadto może przyzwyczaić go do zbierania i przechowywania dokumentacji. Ewidencja podatku VAT jest zatem niezwykle istotna dla rachunkowości, ponieważ stanowi wstęp do jej wprowadzenia w gospodarstwach rolnych. Po 
pewnym okresie rozliczeń z podatku od towarów i usług rolnik będzie czuł się pewnie, będzie posiadał większy zakres wiedzy z tej dziedziny, a także odczuwał większą potrzebę pozyskiwania informacji dla celów zarządzania swoją działalnością. W tej kwestii ewidencja podatkowa nie jest już wystarczająca i zachodzi potrzeba prowadzenia rachunkowości.

\section{Przegląd literatury dotyczącej oceny formy rozliczania podatku VAT $w$ gospodarstwach rolnych}

Wielu ekonomistów zajmowało się już problematyką podatku VAT w rolnictwie. Badania te dotyczyły zarówno wyboru jednej z dwóch prawnie obowiązujących form podatku VAT w rolnictwie, jak i racjonalności jego funkcjonowania. W pierwszym przypadku badane były gospodarstwa o różnym profilu działalności. A. Sadowski i A. Baer-Nawrocka [2011, s. 31] przeprowadzili analizę gospodarstwa rolnego, którego główny kierunek produkcji stanowi tucz trzody chlewnej w cyklu zamkniętym. W badanym okresie rolnik korzystał ze zwolnienia z podatku od towarów i usług. Analiza wykazała, iż w 2010 roku nie było podstaw do rozliczania podatku VAT na zasadach ogólnych. Pośrednią przyczyną był profil prowadzonej działalności, a bezpośrednią - wydatki z nim związane. Rolnik nie inwestował, co przyczyniło się do ekonomicznej opłacalności zryczałtowanego sposobu rozliczania VAT.

Analizę dotyczącą wyboru formy podatku VAT podjęła się również W. Turowska [2010, s. 229], przeprowadzając badania w gospodarstwie o produkcji roślinnej. W tym przypadku opłacalna byłaby rezygnacja ze zwolnienia z podatku VAT. Wpływa na to prowadzenie działalności inwestycyjnej, jak również preferencyjna stawka podatku na produkty rolne. Dodatkowym motywatorem do rezygnacji ze zryczałtowanego zwrotu podatku VAT jest możliwość skorzystania z programów unijnych.

Podobne badania przeprowadziła A. Ginter [2011, s. 41] w grupie 16 gospodarstw rolnych o zróżnicowanym profilu działalności ${ }^{2}$. Analizy te wykazały, iż tylko jedno gospodarstwo prowadzące produkcję roślinną mogłoby z korzyścią finansową zrezygnować z rozliczania podatku VAT na zasadach ogólnych (przy założeniu braku inwestycji w środki trwałe). We wszystkich pozostałych przypadkach zmiana przyniosłaby stratę. Przeprowadzone analizy dowodza, iż rolnicy, których gospodarstwa zostały poddane badaniu, liczą się z konsekwencjami dokonywanego wyboru systemu rozliczeń VAT. Dodatkowo gospodarstwa rolne, które opierają swoją strategię rozwoju na modernizacji parku maszynowego, osiagają korzyści finansowe z bycia podatnikiem VAT.

\footnotetext{
${ }^{2}$ Spośród badanych gospodarstw dziewięć było płatnikami VAT, a pozostali korzystali ze zryczałtowanej formy zwrotu podatku.
} 
W 2003 roku W. Starzyńska i D. Starzyńska [2003, s. 105] dokonały próby analizy opłacalności formy rozliczania podatku VAT w obliczu przystapienia Polski do Unii Europejskiej. Analizowano gospodarstwa podlegające zwolnieniu z podatku VAT. Okazało się, iż z tego tytułu rolnik poniósł straty, a przejście na zasady ogólne spowodowałoby wzrost przychodów, które skłaniałoby gospodarstwo do dalszych inwestycji.

Próba badawcza w postaci rolników prowadzących rachunkowość w ramach ZSRGR (obecnie Polski FADN) była przedmiotem badań w pracy D. Starzyńskiej i J. Wiktorowicz [2006, s. 63]. Analizy tych autorów (już po przystąpieniu Polski do UE) dowiodły, iż przed 1 maja 2004 roku bardziej opłacalne były zasady ryczałtowe dla gospodarstw o następujących profilach działalności: drobiarskich, zajmujących się uprawą zbóż, rzepaku, buraków cukrowych i ziemniaków. Zasady ogólne natomiast były preferowane przez gospodarstwa zajmujące się hodowlą owiec, warzywnictwem i produkcją tzw. pozostałych roślin przemysłowych. Sytuacja zmieniła się po przystąpieniu Polski do Unii Europejskiej i związanej z tym zmianie stawek podatku VAT. Rolnicy, którzy prowadzą gospodarstwo rolne o produkcji zwierzęcej, lecz nie ponoszą wydatków związanych z inwestycjami w środki trwałe, mogą nadal pozostawać przy zwolnieniu z podatku od towarów i usług. Produkcja roślinna natomiast sprzyja decyzji o wyborze zasad ogólnych rozliczenia podatku VAT.

Oceny racjonalności funkcjonowania systemu podatku od towarów i usług na podstawie ankiety przeprowadzonej wśród rolników podjął się R. Rosiński [2013, s. 308]. Jego badania dotyczyły grupy 250 gospodarstw rolnych, z czego $43 \%$ stanowili ryczałtowcy, $23 \%$ płatnicy VAT, a pozostali - gospodarstwa nietowarowe niedokonujące sprzedaży towarów na zewnątrz. Badania te potwierdziły, iż najistotniejszym czynnikiem wyboru metody opodatkowania są wydatki inwestycyjne, a także doradztwo ze strony instytucji zewnętrznych (biura rachunkowe, ośrodki doradztwa rolniczego). Rolnicy, którzy nie zdecydowali się na przejście na zasady ogólne, argumentowali to zbyt małymi osiaganymi dochodami oraz ograniczoną wielkością swojego gospodarstwa. Przyczyną była także obawa przed prowadzeniem ewidencji na potrzeby VAT. Już wcześniej zastrzeżenia te zostały udowodnione przez M. Wasilewskiego i K. Gruziel [2006, s. 144], którzy przeprowadzili ankietę w grupie 101 rolników. Ankietowani przyznali, że system VAT jest zbyt skomplikowany. Według nich metoda ta jest nieopłacalna i stwarza konieczność korzystania z usług biur rachunkowych.

Reasumując, po integracji z Unią Europejską opodatkowanie gospodarstw rolnych podatkiem od towarów i usług stało się bardziej dla nich opłacalne. Większe korzyści finansowe $\mathrm{z}$ tytułu VAT uzyskiwane są jednak $\mathrm{w}$ gospodarstwach o profilu roślinnym, a prowadzenie działalności inwestycyjnej stanowi determinantę wyboru zasad ogólnych rozliczeń tego podatku. Obecnie coraz 
więcej rolników decyduje się na rezygnację z formy zryczałtowanej. Nadal jednak duża ich grupa uważa, iż podatek VAT jest jedynie utrudnieniem. Rolnicy korzystający ze zwolnienia na mocy ustawy o podatku od towarów i usług, nie płacąc VAT, nie mają możliwości odliczenia podatku naliczonego, który zawiera się w dokonywanych przez nich zakupach. Jednak rekompensata, jaką otrzymują $\mathrm{w}$ formie zryczałtowanego zwrotu, często przekracza kwotę podatku naliczonego, co może zostać uznane za subsydiowanie rolnictwa. W tym miejscu pojawia się problem związany $\mathrm{z}$ budżetem państwa. Zryczałtowany zwrot podatku VAT rolników przyczynia się do zmniejszenia dochodów do budżetu, co z kolei wpływa na zmniejszenie funduszy dostępnych dla innych programów rządowych. W rezultacie efekt jest taki sam, jak dokonywanie bezpośredniego wydatku [Dziemanowicz 2007, s. 56]. Obciążenie rolnictwa podatkiem VAT wywołałoby również pozytywny skutek z punktu widzenia budżetu państwa, dlatego też należy prowadzić działania zmierzające do upowszechnienia wiedzy rolników w tej dziedzinie, aby środki finansowe wynikające z nadwyżki z tytułu VAT mogły zasilić budżet ich gospodarstw.

\section{Metodyka i cel badań}

Badania empiryczne przeprowadzono w dwóch gospodarstwach o profilach produkcji roślinnej i zwierzęcej położonych na terenie województwa łódzkiego, w powiecie łęczyckim. Dobór obiektów do badań był celowy. Dane finansowe uzyskano z ewidencji podatku od towarów i usług, a informacje o strukturze upraw i charakterystyce danego gospodarstwa rolnego otrzymano podczas wywiadów pogłębionych z rolnikami. Wśród danych empirycznych zauważyć można rozbieżność stawek podatku VAT w poszczególnych latach. Od 1 stycznia 2011 roku obowiązują nowe regulacje prawne dotyczące podwyższonych stawek podatku od towarów i usług: z 22 na $23 \%$, z 7 na $8 \%$ i z 3 na 5\%. Wydatki, o których mowa w części empirycznej, dotyczą wydatków gospodarstwa rolnego wraz z wydatkami w całości poniesionymi na zakup środków trwałych.

Celem opracowania jest ocena i próba wskazania najkorzystniejszej formy opodatkowania VAT z punktu widzenia profili produkcji roślinnej i zwierzęcej działalności indywidualnego gospodarstwa rolnego.

\section{Wyniki badania empirycznego}

Badane gospodarstwo rolne o profilu produkcji roślinnej posiada 52 ha UR i jest zlokalizowane w województwie łódzkim. W okresach wiosennym i letnim dominuje w nim uprawa warzyw kapustnych, które są na bieżąco sprzedawane 
na rynku hurtowym, a warzywa korzenne (pietruszka, marchew, seler) przeznaczone są do obrotu w okresie zimowym. Po zbiorach przechowywane są w komorach chłodniczych i sukcesywnie przygotowywane do sprzedaży. W okresie letnim rolnik świadczy również usługi kombajnowania zbóż. Każdego roku gospodarstwo korzysta z dopłat bezpośrednich i dofinansowania inwestycji pochodzących z funduszy europejskich (SAPARD - Sektorowy Program Operacyjny, Program Rozwoju Obszarów Wiejskich). Taki profil produkcji wymaga zakupu podstawowych środków do produkcji roślinnej (nawozy, kwalifikowany materiał siewny, środki ochrony roślin).

Gospodarstwo roślinne wyposażone jest we wszystkie niezbędne maszyny rolnicze służące do uprawy gleby, pielęgnacji i ochrony roślin. Mimo to rolnik nadal inwestuje w rozwój gospodarstwa, o czym świadczą inwestycje w środki trwałe. W I kwartale 2010 roku zakupiono ciagnik rolniczy Zetor Forterra o wartości 126 tys. zł brutto. Większość wydatków stanowią zakupy opodatkowane stawkami $22 \%$ i $23 \%$. Należą do nich środki trwałe oraz środki niezbędne do prowadzenia działalności rolniczej.

Badane gospodarstwo o profilu produkcji zwierzęcej posiada ponad 40 ha UR i również położone jest $\mathrm{w}$ centralnym regionie Polski - w województwie łódzkim. Na profil produkcji składa się chów krów mlecznych (stado podstawowe 15 sztuk). Dodatkowo gospodarstwo sprzedaje bydło opasowe. Stado w badanym okresie liczyło 35 sztuk młodych opasów i 15 cieląt. W gospodarstwie uprawia się zboża, kukurydzę oraz trawy. Bydło żywione jest liśćmi buraczanymi, wysłodkami oraz paszą treściwą (zbożem pochodzącym z gospodarstwa). Nadwyżka rocznej produkcji zbóż ma charakter towarowy. W związku z profilem produkcji główne wydatki gospodarstwa związane są z nabywaniem podstawowych środków produkcji zwierzęcej. Są to w szczególności preparaty i dodatki paszowe, w tym koncentraty dla opasów, a także preparaty mlekozastępcze dla cieląt. Gospodarstwo korzysta również z doraźnych usług weterynaryjnych, co związane jest z wydatkiem na zakup leków. Znaczną część wydatków stanowią również zakupy środków do uprawy zbóż i kukurydzy (nawozy, materiał siewny, środki ochrony roślin). Większość opodatkowana jest 23-procentową stawką VAT. W 2011 roku nastąił prawie dwukrotny wzrost wydatków związanych z decyzją rolnika o modernizacji gospodarstwa.

Zarówno gospodarstwo o profilu produkcji roślinnej, jak i zwierzęcej ponosi wydatki ogólnogospodarcze, na które składają się wydatki na: paliwo, energię elektryczną, energię cieplną, wodę, gaz, a także ubezpieczenie społeczne (KRUS) oraz ubezpieczenie majątkowe, podatek rolny, obsługę kredytów bankowych (tab. 1). 
Tabela 1

Struktura wydatków* badanych gospodarstw rolnych o profilach produkcji roślinnej i zwierzęcej w latach 2010-2011

\begin{tabular}{|c|c|c|c|c|}
\hline $\begin{array}{l}\text { Profil produkcji } \\
\text { gospodarstwa } \\
\text { rolnego }\end{array}$ & Lata & Kwartały & Wydatki brutto [zł] & VAT naliczony [zł] \\
\hline \multirow{10}{*}{ Roślinne } & \multirow{5}{*}{2010} & 1 & 177046 & 33594 \\
\hline & & II & 48062 & 6274 \\
\hline & & III & 55217 & 7812 \\
\hline & & IV & 192103 & 39674 \\
\hline & & razem & 472428 & 87354 \\
\hline & \multirow{5}{*}{2011} & 1 & 193915 & 26990 \\
\hline & & II & 64629 & 11764 \\
\hline & & III & 39160 & 7912 \\
\hline & & IV & 66415 & 13196 \\
\hline & & razem & 364119 & 59862 \\
\hline \multirow{10}{*}{ Zwierzęce } & \multirow{5}{*}{2010} & 1 & 46397 & 4695 \\
\hline & & II & 39929 & 4380 \\
\hline & & III & 14673 & 1909 \\
\hline & & IV & 16162 & 1482 \\
\hline & & razem & 117161 & 12466 \\
\hline & \multirow{5}{*}{2011} & $\mathrm{I}$ & 58691 & 6139 \\
\hline & & II & 81272 & 7814 \\
\hline & & III & 34286 & 5287 \\
\hline & & IV & 74005 & 10630 \\
\hline & & razem & 248254 & 29870 \\
\hline
\end{tabular}

*Badania dotyczą wydatków gospodarstwa rolnego wraz z wydatkami w całości poniesionymi na zakup środków trwałych.

Źródło: Opracowanie własne na podstawie wywiadu z rolnikiem.

Na przychody z działalności gospodarstwa roślinnego składa się w głównej mierze przychód ze sprzedaży warzyw opadatkowany odpowiednio stawkami VAT: 3\% w 2010 roku i 5\% w 2011 roku. Struktura przychodów gospodarstwa rolnego jest raczej jednorodna. W obu badanych latach dominuje sprzedaż warzyw opodatkowana najniższą stawką, która stanowi ponad $90 \%$ obrotu. W 2010 roku pojawiła się sprzedaż zwolniona z podatku, na którą składa się usługa kombajnowania. Po zmianie przepisów w 2011 roku usługa ta została obciążona 5-procentową stawką podatku VAT. W IV kwartale 2011 roku rolnik dokonał sprzedaży części starego parku maszynowego, stąd też występują 
przychody opodatkowane 23-procentową stawką VAT. Podwyższenie stawek podatku VAT w 2011 roku przyczyniło się do znacznego wzrostu kwot podatku VAT, rozliczanego zarówno na zasadach ogólnych, jak i w formie zryczałtowanej. Przy wzroście przychodów ze sprzedaży o $20 \%$ podatek VAT należny wzrósł prawie trzykrotnie, a jego zryczałtowana forma o ponad $34 \% \mathrm{w}$ porównaniu $\mathrm{z}$ rokiem poprzednim (tab. 2).

\section{Tabela 2}

Struktura przychodów badanych gospodarstw rolnych o profilach produkcji roślinnej i zwierzęcej w latach 2010-2011

\begin{tabular}{|c|c|c|c|c|c|c|}
\hline $\begin{array}{l}\text { Profil produk- } \\
\text { cji gospodar- } \\
\text { stwa rolnego }\end{array}$ & Lata & Kwartały & $\begin{array}{c}\text { Stawka } \\
\text { podatku } \\
{[\%]}\end{array}$ & $\begin{array}{c}\text { Wartość } \\
\text { netto } \\
\text { sprzedaży } \\
\text { [zł] }\end{array}$ & $\begin{array}{c}\text { VAT należny } \\
\text { [zł] }\end{array}$ & $\begin{array}{c}\text { Zryczałto- } \\
\text { wany zwrot } \\
\text { podatku VAT } \\
\text { [zł] }\end{array}$ \\
\hline \multirow{13}{*}{ Roślinna } & \multirow{6}{*}{2010} & I & 3 & 30740 & 922 & 1844 \\
\hline & & II & 3 & 113400 & 3402 & 6804 \\
\hline & & \multirow{2}{*}{ III } & zwolniona & 15000 & - & - \\
\hline & & & 3 & 87325 & 2620 & 5239 \\
\hline & & IV & 3 & 12714 & 381 & 763 \\
\hline & & razem & $x$ & 259179 & 7325 & 14650 \\
\hline & \multirow{7}{*}{2011} & 1 & 5 & 111480 & 5574 & 7804 \\
\hline & & II & 5 & 146320 & 7316 & 10242 \\
\hline & & III & 5 & 16932 & 847 & 1185 \\
\hline & & \multirow{3}{*}{ IV } & 5 & 4412 & 221 & 309 \\
\hline & & & 8 & 1600 & 128 & 112 \\
\hline & & & 23 & 30000 & 6900 & - \\
\hline & & razem & $x$ & 310744 & 20986 & 19652 \\
\hline \multirow{12}{*}{ Zwierzęca } & \multirow{5}{*}{2010} & 1 & 3 & 18498 & 555 & 1110 \\
\hline & & II & 3 & 15932 & 478 & 956 \\
\hline & & III & 3 & 19337 & 580 & 1160 \\
\hline & & IV & 3 & 11478 & 352 & 689 \\
\hline & & razem & $x$ & 65245 & 1965 & 3915 \\
\hline & \multirow{7}{*}{2011} & 1 & 8 & 8976 & 718 & 628 \\
\hline & & II & 8 & 36861 & 2949 & 2580 \\
\hline & & \multirow{2}{*}{ III } & 5 & 11580 & 579 & 811 \\
\hline & & & 8 & 46942 & 3755 & 3286 \\
\hline & & \multirow{2}{*}{ IV } & 5 & 5630 & 282 & 394 \\
\hline & & & 8 & 37186 & 2975 & 2603 \\
\hline & & razem & $x$ & 147175 & 11258 & 10302 \\
\hline
\end{tabular}

Źródło: Opracowanie własne na podstawie wywiadu z rolnikiem. 
W 2010 roku poziom sprzedaży gospodarstwa o profilu produkcji zwierzęcej wynikał głównie ze sprzedaży mleka i z drobnej nadwyżki ziarna zbóż. W 2011 roku gospodarstwo odnotowało ponaddwukrotny wzrost poziomu przychodów, co było spowodowane (prócz regularnej sprzedaży mleka) wyprzedażą części stada młodych opasów. Efekt tych transakcji został odzwierciedlony w podatku należnym, który wzrósł w porównaniu z 2010 roku o 9293 zł, a zryczałtowany zwrot wyniósłby zaledwie 10302 zł wobec 3915 zł w 2010 roku. Tak dużych wpływów rolnik nie jest jednak w stanie generować corocznie. Wynika to ze specyfiki hodowli stada opasowego. Chów młodego żywca wołowego trwa bowiem półtora roku, a więc przy zrównoważonej hodowli takie przychody odnotowywane mogą być co drugi rok. Większe wartości podatku należnego i zryczałtowanego zwrotu wynikają również ze zmiany przepisów podatkowych.

W tabeli 3 zaprezentowano wyniki analizy różnych form rozliczania podatku od towarów i usług. W badanych latach najbardziej opłacalną formą dla gospodarstwa roślinnego są zasady ogólne, pomimo wzrostu w 2011 roku wartości zryczałtowanego zwrotu o 5002 zł. Wynika to ze struktury wydatków (charakterystycznej dla produkcji roślinnej), w których przeważają zakupy opodatkowane najwyższymi stawkami VAT - 22 i 23\%. Zwrot z tytułu VAT rozliczanego na zasadach ogólnych w 2010 roku był aż o ponad 65 tys. zł większy od zryczałtowanego zwrotu. Rolnik może przeznaczyć pozyskane środki na dodatkowe inwestycje w park maszynowy bądź budynki gospodarcze. Zryczałtowana forma spełniłaby takie oczekiwanie inwestycyjne w przypadku wydatków na produkty opodatkowane niskimi stawkami VAT. W przypadku aktualnej formy rozliczania się z tytułu VAT rolnik ma możliwość odliczenia dużych wydatków związanych z prowadzeniem działalności rolniczej. Wyniki badań jednoznacznie wskazuja, iż przy obecnych stawkach podatku VAT, analizowanej strukturze produkcji,

Tabela 3

Porównanie form rozliczania podatku od towarów i usług

\begin{tabular}{|l|c|c|c|c|c|c|}
\hline $\begin{array}{l}\text { Profil produkcji } \\
\text { gospodarstwa } \\
\text { rolnego }\end{array}$ & Lata & $\begin{array}{c}\text { VAT } \\
\text { należny } \\
\text { [zł] }\end{array}$ & $\begin{array}{c}\text { VAT } \\
\text { naliczony } \\
\text { [zł] }\end{array}$ & $\begin{array}{c}\text { Zwrot na } \\
\text { zasadach } \\
\text { ogólnych } \\
\text { [zł] }\end{array}$ & $\begin{array}{c}\text { Zryczałtowany } \\
\text { zwrot podatku } \\
\text { VAT [zł] }\end{array}$ & Różnica \\
\hline \multirow{4}{*}{ Roślinna } & 2010 & 7325 & 87354 & 80029 & 14650 & 65379 \\
\cline { 2 - 8 } & 2011 & 20986 & 59862 & 38876 & 19652 & 19224 \\
\cline { 2 - 8 } & różnica & 13661 & -27492 & -41153 & 5002 & - \\
\hline \multirow{3}{*}{ Zwierzęca } & 2010 & 1965 & 12466 & 10501 & 3915 & 6586 \\
\cline { 2 - 8 } & 2011 & 11258 & 29870 & 18612 & 10302 & 8310 \\
\cline { 2 - 8 } & różnica & 9293 & 17404 & 8111 & 6387 & - \\
\hline
\end{tabular}

Źródło: Opracowanie własne. 
prowadzonej działalności inwestycyjnej oraz relacjach cenowych zasadny był wybór zasad ogólnych rozliczania podatku VAT przez omawiane gospodarstwo rolne.

Podobne stwierdzenie dotyczy gospodarstwa o profilu produkcji zwierzęcej. Biorąc pod uwagę badany przedział czasowy, uzasadniony jest wybór zasad ogólnych rozliczania podatku VAT. Po zmianie przepisów w 2011 roku zryczałtowany zwrot podatku VAT byłby mniejszy o $8310 \mathrm{zł} \mathrm{w}$ porównaniu ze zwrotem uzyskanym $\mathrm{z}$ rozliczenia na zasadach ogólnych. W porównaniu do gospodarstwa o profilu produkcji roślinnej wartości podatku naliczonego są znacznie mniejsze. Decydujące znaczenie ma jednak 23-procentowa stawka podatku VAT płacona w cenie zakupionych materiałów. W przypadku gospodarstw hodowlanych występuje mniejsza ilość zakupów obciążonych najwyższą stawką podatku VAT. Rezygnując ze statusu czynnego płatnika VAT i tym samym powracając do zwolnienia z podatku VAT, rolnik utraciłby 14896 zł. Takie środki są wystarczające na utrzymanie hodowli przez rok.

\section{Wnioski końcowe}

Z przeprowadzonych analiz jednoznacznie wynika, iż:

1. Najbardziej opłacalną formą rozliczania podatku od towarów i usług są zasady ogólne. Dotyczy to zarówno gospodarstwa rolnego zajmującego się produkcją roślinna, jak i gospodarstwa o profilu produkcji zwierzęcej. W największym stopniu decyduje struktura wydatków, w której przeważają wydatki na towary opodatkowane najwyższymi stawkami VAT: 22 oraz $23 \%$.

2. Możliwość pełnego odliczenia podatku VAT staje się stymulatorem modernizacji gospodarstw rolnych. Należy zwrócić uwagę na konieczność podejmowania przedsięwzięć inwestycyjnych w małych i średnich gospodarstwach towarowych, gdyż wpływa to pozytywnie na wysokość zwrotu $\mathrm{z}$ tytułu podatku VAT. Dodatkowym impulsem do działania mogą być fundusze unijne.

3. Rozliczanie podatku VAT na zasadach ogólnych okazało się być korzystniejszą formą $\mathrm{w}$ gospodarstwie o produkcji roślinnej. W badanym gospodarstwie rolnik ponosi bardzo duże wydatki na zakup środków niezbędnych do prowadzenia działalności, ale także inwesuje fundusze w poszerzanie parku maszynowego. Działania takie w znacznym stopniu wpływają na wysokość podatku naliczonego.

4. Gospodarstwo rolne o profilu produkcji zwierzęcej czerpie znacznie mniejsze korzyści finansowe z podatku VAT bez względu na wybór formy rozli- 
czania. Należy zwrócić uwagę, iż w porównaniu do gospodarstwa o produkcji roślinnej różnica między zasadami ogólnymi a zryczałtowanym zwrotem z podatku VAT $\mathrm{w}$ gospodarstwie o produkcji zwierzęcej jest niewielka (tab. 3). Taka sytuacja może wpływać na wątpliwości rolnika co opłacalności i w konsekwencji doprowadzić do tego, że zrezygnuje ze zwolnienia $\mathrm{z}$ podatku VAT.

Pamiętać przy tym należy, iż wyniki te są prawidłowe jedynie dla dwóch badanych w opracowaniu gospodarstw. Wybór optymalnej formy opodatkowania jest sprawą indywidualną każdego rolnika, zależną od wielu czynników, m.in.: ekonomicznych, organizacyjnych, formalnych oraz prawnych. Przed dokonaniem wyboru należy przeanalizować wszystkie aspekty, w tym wielkość danego gospodarstwa oraz profil i skalę produkcji.

\section{Literatura}

ARSENOVIC D., LALIC S., STANIVUK B., NJEGUS B., 2012: Agriculture in the VAT system, RJAS 44 (3), 227-232.

BIELĘDA T., KOŃCZAL H., RYBACKA K., SINIECKA M., 2012: VAT w pytaniach $i$ odpowiedziach. Poradnik na 2012 rok, Wydawnictwo Podatkowe GOFIN, Gorzów Wielkopolski.

DZIEMANOWICZ R.I., 2007: Opodatkowanie jako forma wsparcia rolnictwa, Zagadnienia Ekonomiki Rolnej 2, 42-59.

FRECAUTEANU A., CHISLARU A., 2013: VAT taxation on agricultural products - a controversial elements of fiscal management in the Republic of Moldova, Scientific Papers Series Management Economic Engineering in Agriculture and Rural Development 13, 2, 159-163.

GINTER A., 2011: Korzyści finansowe z tytulu podatku VAT w wybranych gospodarstwach rolnych dokonujacych inwestycji, Zeszyty Naukowe SGGW EiOGŻ 92, 41, 41-49.

ROSINSSKI R., 2013: Motywy wyboru metody rozliczania podatku od towarów i ustug $w$ działalności rolniczej, Roczniki Naukowe SERiA 15, 2, 308-312.

SADOWSKI A., BAER-NAWROCKA A., 2011: Ekonomiczne przestanki sposobu rozliczania podatku VAT w gospodarstwach rolnych w świetle zmian przepisów w 2011 roku, Zeszyty Naukowe SGGW EiOGŻ 92, 31-39.

STARZYŃSKA W., STARZYŃSKA D., 2003: VAT w rolnictwie - ocena ekonomicznych konsekwencji wprowadzenia tego podatku, Instytut Ekonomii Filii Akademii Świętokrzyskiej w Piotrkowie Trybunalskim, Zeszyt Naukowy 4, 105-131.

STARZYŃSKA D., WIKTOROWICZ J., 2006: Ocena korzyści wynikajacych z wyboru systemu VAT-owskiego dla polskich rolników, [w:] VAT w rolnictwie, W. Starzyńska (red.), Wydawnictwo Uniwersytetu Łódzkiego, Łódź.

TUROWSKA W., 2010: Ewidencja, rozliczanie i skutki rozrachunków przedsiębiorstw rolniczych z tytułu podatku VAT, Zeszyty Naukowe SGGW EiOGŻ 82, 229-238. 
Ustawa z dnia 11 marca 2004 roku o podatku od towarów i ustug (Dz.U. 2004 nr 54, poz. 535 ze zm.).

WASILEWSKI M., GRUZIEL K., 2006: Funkcjonowanie podatku VAT w opiniach rolników indywidualnych, Roczniki Nauk Rolniczych, G 1, 93, 1, 144-151.

ZABIELSKA D., 2011: Uwarunkowania zasad funkcjonowania podatku VAT w gospodarstwach rolnych, Zeszyty Naukowe SGGW EiOGŻ 89, 61-74.

\section{Abstrakt}

Celem artykułu jest ocena i próba wskazania najkorzystniejszej formy opodatkowania VAT z punktu widzenia profilu działalności indywidualnego gospodarstwa rolnego. Autorzy dokonali analizy dotychczas przeprowadzonych krajowych badań w zakresie opłacalności formy podatku VAT. Zarówno analiza literatury, jak i rezultaty przeprowadzonych badań wykazują najwięcej ekonomicznych korzyści z wyboru opodatkowania VAT na zasadach ogólnych. Zwraca się przy tym uwagę na konieczność przeprowadzenia regularnych inwestycji w gospodarstwie, które mogą zagwarantować zwrot podatku od towaru i usług. Największe nadwyżki podatku naliczonego nad należnym odnotowano $\mathrm{w}$ gospodarstwie o profilu produkcji roślinnej, co stanowi o przeważającej opłacalności tego profilu działalności z punktu widzenia wyboru formy opodatkowania VAT.

Słowa kluczowe: podatek VAT, zryczałtowany zwrot podatku, zasady ogólne

\section{Profitability of settlement scheme VAT in activities of individual farms}

\section{Abstract}

The aims of the paper are to estimate and indicate the most favorable VAT settlement scheme in individual farms. Authors analyzed previous domestic research in terms of profitability of various VAT forms. Both, the analysis of literature and own research, show that it is the most profitable for the farmers to pay VAT according to the general principles. The article pays attention to the need for regular investment on the farm due to greater benefits of VAT. The biggest difference between charged tax and tax due was noticed on a farm with plant production. It means, that plant production is much more rational form the point of view of VAT form.

Key words: VAT, lump-sum tax, general principles 